\title{
The migration industry in the United States, 1882-1924
}

\author{
Ivan Light*
}

*Department of Sociology, Box 951551, University of California, Los Angeles, CA 90095 USA. Email: light@soc.ucla.edu

\begin{abstract}
Recent interest in the migration industry has produced no consensus on its boundaries. Some researchers limit the concept to travel-related business; others expand the scope to include additional immigration-supporting commercial businesses, legal and illegal. Using historical evidence, this article addresses treatment of the migration industry in the late 19th and early 20th centuries. These treatments introduced the same conceptual issues that are resurfacing today. Examining immigrant bankers, international sex traffickers, and saloon keepers in the period 1882-1924, the article makes a systemic case for expanding the boundaries of the migration industry beyond the limitations of the transportation industry, but acknowledges the validity of the narrower concept. The exercise also adds a historical dimension to this contemporary concern.
\end{abstract}

Keywords: alcohol, banks, ethnic economy, migration industry, sex trafficking

\section{Introduction}

During approximately the last quarter century, social science literature on international migration has heavily stressed agents and institutions that amplify migratory pushes and pulls, the prime movers of classical migration theory (Johnston, Karageorgis and Light in press). These are migration facilitators. Of these facilitators by far the most prominent is the migration network that, once linked into what Douglas Massey and his colleagues (1987; Massey 1999: 45-7) have called 'cumulative causation', begins actually to drive migration, displacing in part the push/pull processes that initiated the migration. The migration network is by far the most studied facilitator, and has become a required component of migration theory and research (De Haas, 2010: 1588; Light, 2006: 2, 23-6).

But, in addition to the migration network, another, much smaller literature has identified a second facilitator, the migration industry. This topic has been studied in geography, political science, social anthropology and sociology. Like the migration network, the migration industry facilitates immigration, reducing the frictions of migration without amplifying distress in the sending countries or opportunities in the receiving country (Salt and Stein, 2002). ${ }^{1}$ The migration industry also generates a pro-migration political and economic constituency in reception countries. In so doing, the migration industry accentuates 
and accelerates existing migrations just as does the migration network, and for this reason the two, conceptually distinct, processes may be regarded as related migration facilitators.

As commonly occurs with newer concepts, several controversies have arisen concerning the boundaries of a migration industry, its individual components, and even its antiquity. The apparent originators of this terminology, Salt and Stein (2002: 468) have defined a migration industry as networks, agents, and individuals that 'stand to make a commercial gain' from migration, and the authors have applied their formulation specifically to the international sex traffic. A migration business would represent a firm within the migration industry. In their judgment (2002: 484) too, their concept represents 'a first step toward conceptualizing migration as an international business'. According to Stephen Castles (2007: 36), a migration industry arises from migration already under way in response to emergent needs for a variety of special services. Migration industries consist of business firms that provide the services that migrants need in order to migrate. Castles offered an ostensive definition of the migration industry's membership. The migration industry includes 'travel agents, lawyers, bankers, labor recruiters, brokers, interpreters, and housing agents'. All these agents have 'an interest in the continuation of migration, and may go on organizing it even when governments try to restrict movements'. The facilitation of migration is a 'major and largely legal business'. Castles said 'largely legal' in order to include in his definition of migration industry the transportation agents whose business consists in landing illegal migrants in violation of national immigration laws.

Objecting to this formulation, Herman (2006: 194) declares the concept of migration industry just 'an economic metaphor' because migration 'is not a business'. Herman argues that Salt and Stein's concept of migration industry wrongly conflates personal networks and profit-seeking individuals and organizations. Social networks promote migration through cumulative causation; profit seekers through business enterprise. However, personal social networks are not profit-seeking, their known effects on migration are huge; and their operation cannot be declared a business; hence, Herman concludes, migration cannot be 'an international business' as Salt and Stein (2002: 484) and others have declared it. Herman also observes that the concept of chain migration, a precursor concept to network migration, was already well understood in the United States in 1907, but she does not critique Salt and Stein's claim to have been the first ever to conceptualize international sex traffic as a business enterprise, and seems, indeed, to accept that claim.

Herman's criticism of the concept of migration industry lacks support in the social science literature, which sharply differentiates personal social networks from a migration industry. Salt and Stein's definition of migration industry excluded the personal networks of immigrants, and other scholars agree. Thus, Rubén Hernández-León (2008: 154; also see Lindquist, 2010) has defined the migration industry as 'the ensemble of entrepreneurs who ... provide a variety of services facilitating human mobility across international borders'. Locating the migration squarely in the private business sector, his definition of the migration industry excludes kinship and friendship networks of whose independent contribution to migration Hernández-León is acutely aware. In agreement with HernándezLeón, Lindquist, and with Castles, Garapich (2008: 735) defined the migration industry as 'specialised social actors and commercial institutions that profit directly' from immigration. Focusing on the ethnic tourist industries in European cities, Rath and Swagerman (2011) also trace the tourism industry's special interest in perpetuating immigration. Thus 
defined, in the work of all these scholars, the sector of personal social networks is no part of the migration industry, which consists of business firms. Personal networks are the major contributor to migration, but they are not a definitional part of the migration industry.

However, Garapich's orthodox definition of a migration industry, which includes only business firms, also introduces a novel component that requires but has not hitherto received independent consideration. This is how widely to expand the definition of a migration industry. On Garapich's definition, which extends in this respect the one offered earlier by Castles, and simultaneously by Favell (2008), the businesses that make up the migration industry include not only those that profit directly from migration, such as travel agencies or airlines, but also those that profit financially or depend economically upon immigrant 'adaptation', a term that includes acculturation, economic integration, and assimilation. These constitute a vast baggage to add to transportation agencies, the migration industry's conceptual core. Garapich mentions foreign-language news media, as had Robert Park (1922), but other immigrant-dependent industries could easily be added to his list. Realizing that this redefinition drops most of the ethnic enclave economy into the migration industry, where an ethnic enclave economy is the ethnic-servicing sector of an ethnic economy (Light et al. 1994; Rath and Swagerman 2011), Garapich observes that the migration industry thus defined could well include more than co-ethnics, and should be differentiated on this ground from an ethnic enclave economy. If so, the number of migration-servicing industries would be vastly expanded.

\section{Historical evidence}

What ought to be the conceptual boundaries of the migration industry, how old is the concept, and what have we learned about it in a century? The history of social science can address all these questions, expand the boundary of empirical study, and even clarify definitional issues that contemporary researchers debate. Evidence from the history of social science also identifies the antiquity of the migration industry, validating the concept's empirical longevity, and identifying the date at which the concept (if not the words) entered social science discourse. The historical archive of social science also offers access to the most informed and most scrupulously accurate observers of immigration as it existed a century or more ago. There are also, of course, direct linkages between their concerns and many of those that animate contemporary social science approaches to immigration.

Finally, and most importantly, the historical archive of social science also permits a discussion of the extent to which adaptive agencies rightly belong, as Garapich has claimed, within the concept of migration industry or whether the concept should be more narrowly defined, following Hernández-León, to include only transportation agencies. The difference is approximately this. If the migration industry is narrowly defined, it includes only commercial agencies that transport immigrants such as airlines, bus companies, and steamship lines. If broadly defined, it includes, in addition to the above, all commercial firms that depend upon the custom of immigrants for most or even all of their revenues. Even a brief review of the history of European immigration in the late nineteenth and early twentieth century shows that both the narrow and the broad conception of a migration industry were implicit in the social science archive. 
The period 1882 to 1924 represented the peak years of European immigration to the United States during the late nineteenth and early twentieth century. Indeed, as a percentage of total population, the share of immigrants climbed to levels in 1910 that immigration approached again in 2010 but did not equal. This 42 -year period is also bounded by two key legislative enactments: the Chinese Exclusion Act of 1882, and the Immigration Act of 1924, which introduced the national origins quota system. ${ }^{2}$ Chinese exclusion was the first exclusionary legislation ever introduced in the United States and, as the name suggests, it was intended to restrict the access of Chinese to the United States. ${ }^{3}$ The national origins quota system assigned all nationalities numerical quotas based on each one's share of the United States population in 1890, and, when later amended, in 1920. In this way, the framers of the legislation inhibited so-called 'new immigration' from eastern and southern Europe. These new immigrants they considered less desirable than immigrants from northwestern Europe. As these boundary-defining political events also imply, the whole 42-year period was one of intensifying restrictionism that finally rejected the liberal and integrationist sentiments of Emma Lazarus, written earlier but inscribed in 1903 on the base of the Statue of Liberty in New York Harbor.

\section{The migration industry, $1882-1924$}

Disturbed by the high volume of European immigration, especially from eastern and southern Europe, the United States Senate undertook a massive study of immigration in 1910-11. The Commission's Chair and the nominal compiling editor of this 41-volume endeavor was William Paul Dillingham, but the whole project became known subsequently as the Dillingham Commission (Zeidel 2004). Publishing in 1911, the Dillingham Commission distinguished basic and contributory causes of migration to the United States. The basic cause was, of course, the high-paying jobs in the United States. Without the desirable jobs, the Commission understood, Europeans would not have emigrated in vast numbers. However, the Dillingham Commission also concluded that, in addition to jobs, the basic condition, several contributory factors were increasing immigration beyond the optimal level. Chief among these contributory factors, the Dillingham Commission (US Senate 1911: 56; also Hourwich 1912: 4, 93-4) declared, was 'the advice and assistance of relatives or friends who have previously emigrated', a conclusion that contemporary historians fully accept (Bodnar 1985: 57). The Dillingham Commission (U.S. Senate 1911: 59) found that 'nearly all European immigrants admitted to the United States had acknowledged 'going to join relatives or friends'. A decade later, Jenks and Lauck (1922: 2) also declared that 'In the large majority of cases ... the immediate inducement to the emigrants to leave home and sail for America come in the form of personal letters from friends or members of their own families already in the United States'. Of course, the advice of friends and relatives did not create the jobs that European immigrants intended to obtain; in that sense, the advice of friends and relatives was not a basic cause of emigration. But the advice of friends and relatives did promote awareness of those jobs in emigration districts, and in this way secondarily encouraged emigration. The assistance of friends and relatives further enabled those, already possessed of information, to realize their plan for emigration. All this information and assistance was offered at no 
monetary cost to potential emigrants by parties who did not make a business of promoting emigration.

In addition to the advice and assistance of friends and relatives, which immigration researchers would now identify as network-driven immigration, the Dillingham Commission (US Senate 1911: 61-2; also Jenks and Lauck 1922: 21) identified a second and, in their opinion, barely less important contributory cause of emigration. This contributor was 'the propaganda conducted by steamship ticket agents'. This propaganda flourished 'in every emigrant-furnishing country of Europe'. In the Austro-Hungarian province of Galicia alone, 5,000 steamship agents peddled tickets to the United States (Jenks and Lauck 1922: 22). By identifying the steamship companies' advertising as 'propaganda' rather than information, the Dillingham Commission implied that the steamship ticket agents presented an overly rosy view of immigration that ignored its hardships and risks. Robert Park (1922: 338) concurred, pointing out that steamship companies had even purchased foreign language newspapers to obtain access to their subscriber lists. The steamship companies' underlying motive was to promote ticket sales because their revenue depended upon selling tickets to emigrants. The more people who emigrated, the more tickets the steamship companies sold, and the greater was their revenue. The more attractive their image of what the United States offered, the more people would opt to emigrate. Then as now, advertising paid.

Unlike friends and relatives, who had the welfare of a potential emigrant at heart, the steamship companies knew no benevolent restraint. Exaggeration sold more tickets than the sober truth. In this way, many poorly educated Europeans embarked for the United States in the expectation of finding a land whose streets were 'paved with gold' as the saying went. Kamphoefner (2009) protests that this official view underestimated the salutary correction that friends and relatives provided to the steamship companies' propaganda. But authorities on both sides of the Atlantic persisted in this view nonetheless, and, in any case, the steamship companies' persistent advertising perpetually renewed the glamorous image of the United States against which more sober assessments had continually to battle.

Fourteen years after the Dillingham Commission published its report, Henry Pratt Fairchild, a major academic authority, and a proponent of immigration restriction, made a distinction similar in spirit to what the Dillingham Commission had earlier proffered but conceptually more advanced. Fairchild (1925: 147) distinguished 'natural causes' of immigration from 'artificial causes'. Natural causes reflected the superiority of economic conditions in the destination relative to the country of origin. Natural causes could include climate, soil, and health conditions as well as jobs but all were fundamentally economic. In contrast, what Fairchild called 'artificial causes' only reflected the stimulation of 'the desire and determination to migrate' by the induction of 'dissatisfaction with existing conditions'. The artificial was psychological; the real was material. The source of the artificial stimulation, Fairchild (1925: 151) declared, was invariably 'some interested person or agency whose motive may or may not be selfish'. Fairchild identified two sets of culprits. The culprits were family and friends on the one side, and steamship companies and labor agents on the other. Fairchild thus lumped together the advice and assistance of friends and relatives (whose motive was not selfish) and the advertising of the steamship companies, which the Dillingham Commission had distinguished and which Herman (2006) also firmly distinguished. Fairchild added 'labor agents' to the steamship companies on the 
commercial side, and expressed disdain for the commercial mendacity of both the steamship companies and the labor agents. 'The getting of immigrants is now a thoroughly developed system, planned to serve the needs of every form of interest which might profit thereby.' The mendacity of the steamship companies and labor agents gave potential émigrés an overly rosy picture of the life they could realistically expect in the United States. As a result, Fairchild concluded, more people emigrated from Europe than really would have done so if sober realism and natural causes had governed their judgment.

Despite the slight differences between their formulations, the Dillingham Commission's distinction between basic and contributory causes of immigration and Fairchild's distinction between natural and artificial causes were animated by a common perception. Both perceived that immigration to the United States was greater in volume than it should have been because of external stimulation through advertising. True, the economist Issac Hourwich (1912: 11) rejected the connection between 'oversupply' of immigrants and the job loss of native workers, but (1912: 114-47) devoted 33 pages to immigrant 'unemployment'. Thanks to false advertising, we might say, summarizing the consensus, more Europeans 'consumed immigration' than would otherwise have done so. In the lexicon of the Dillingham Commission, steamship company propaganda had swelled the volume of European immigration beyond the job supply. In the Fairchild lexicon, the natural level of immigration had been exceeded because of advertising which was transmitted to the European working class through the exaggerations and mendacity of labor agents abroad and steamship companies, their employers. In either version, the United States had received appreciably more immigration from Europe than it needed as a result of commercial interests that promoted emigration through publicity and price competition. In the course of the immigration process, these commercial interests had perfected the technique of inducing more people to migrate than should have done so. The unfortunate result was a glut of immigrants, and an exacerbation of immigrant poverty in the United States.

\subsection{Legal barriers to emigration}

These findings were not surprising even at the time. The Commission's theoretical opinion was already written into US law when the Dillingham Commission published its results. Two decades before the Dillingham Commission reported, the perception of surplus immigration was so widely shared in the United States that it had influenced American immigration law and indirectly influenced European law as well. As the Dillingham Commission pointed out in 1911, the US Immigration Act of 1885, reiterated in 1891, forbade the entry of 'contract laborers'. Contract laborers were defined as persons 'who have been induced or solicited to migrate to this country by offers or promises of employment' usually made to them by labor agents, many of them in the employ of steamship companies. Inducing people to migrate by false promises of employment was the heart of the immigration problem that the law wished to rectify. The intent of this regulation was to deprive labor contractors in Europe of their ability to promise employment in the United States to working class Europeans. Under a strict interpretation of this law, the Dillingham Commission (US Senate 1911: 60) noted, any immigrant was a contract laborer who had a promise of employment in the United States prior to embarkation in Europe. Alas, declared the Dillingham Commission (US Senate 1911: 60), 'it is certain that European immigrants' 
were 'for the most part contract laborers, for it is unlikely that many emigrants embark for the United States without a pretty definite knowledge of where they will go and what they will do if admitted'. The American law tried but failed to disconnect the labor agents' capacity to encourage emigration, a sure sign that the stimulative role of labor agents was known to the framers of this legislation in 1891.

Another unsuccessful legal obstacle was Section 7 of the US Immigration Act of 1891. This section provided that 'no transportation company or owner or owners of vessels, or others engaged in transporting aliens into the United States, shall, directly, or indirectly, either by writing, printing, or oral representation, solicit, invite, or encourage the immigration of any aliens into the United States'. The intent of this regulation was to disconnect the ability of steamship companies to delude Europe's huddled masses with idle dreams of easy prosperity in the United States. The Dillingham Commission (US Senate 1911: 61-2) acknowledged that the steamship companies themselves did not violate this regulation. However, the Commission maintained that their local ticket agents rampantly did so. 'It is clear that these local agents as a rule, solicit business, and consequently encourage emigration, by every possible means.' In effect, then, the steamship companies conducted the very pro-emigration propaganda barrage that the American immigration law had hoped to prevent.

Violations were most rampant in Italy and southern Europe, regions from which restrictionists most wanted to inhibit emigration. Although Italian law forbade the solicitation of emigration by steamship companies, local ticket agents did so anyway. The Dillingham Commission (US Senate 1911: 64) reported that 'steamship agents solicit business much as insurance agents do, and that in many instances they do not concern themselves with the character or mental or physical condition of their customers, their sole object being to increase their commissions'. One method was to translate editorials and articles from American newspapers relative to the prosperity of the United States, and then to distribute these articles among prospective emigrants. Steamship agents even passed out printed cards bearing hymns of praise to the United States at the doors of Italian churches.

In an additional effort to discourage the steamship companies from propagandizing for emigration, the United States Immigration Act of 1891 had required that 'unlawful aliens' arriving in the United States by ship should be 'immediately sent back on the vessel by which they were brought in. The cost of their maintenance while on land, as well as the expense of the return of such aliens, shall be borne by the owner or owners of the vessel on which such aliens came.' The intent of this regulation was to saddle the steamship companies with the cost of repatriating rejected immigrants, and thus to deter them from promoting the emigration of persons obviously unfit for admission to the United States. ${ }^{4}$

To some extent, this regulation proved successful because it precipitated self-defensive laws among labor-exporting states of Europe, especially those whose harbors were embarkation points for immigrants to the United States. These European states did not want to care for rejected emigrants whom the steamship companies brought back impecunious from American ports. To inhibit this unwanted result, Germany had compelled the steamship companies to maintain 13 control stations on Germany's borders with Russia and Austria-Hungary. ${ }^{5}$ These stations examined emigrants bound for the United States from German ports, debarring any from entering Germany who would obviously fail US immigration tests, be returned to Europe, and then become welfare burdens on 
Germany. The strategy worked. The Dillingham Commission (1911: 77; also Fairchild 1925: 175) reported that five emigrants were turned back in Europe in this way for every one turned away in the United States.

Although neither the Dillingham Commission of 1911 nor Henry Pratt Fairchild, writing in 1913, would have understood the words 'migration industry', the underlying awareness was already present in 1911 and even in 1891. The Dillingham Commission, the framers of the Immigration Act of 1891, and Henry Pratt Fairchild all understood that transportation companies represented a vested economic interest in the stimulation and encouragement of emigration from Europe. This interest had pumped up emigration beyond levels that would otherwise have obtained. The migration industry was their culprit, blamed for inflating migration above optimal levels.

Locating the migration industry squarely in the private business sector, our contemporary definition of the migration industry excludes the kin and friends whom, along with the steamship companies, Henry Pratt Fairchild blamed for artificially exaggerating the numbers of emigrants. Kin and friends are not a business at all, their advice is non-commercial, and, confirming Herman (2006), network migration was no more a business then than it today. But it is also true that emigrants abroad sometimes fed back deceptively optimistic statements of their own economic status in the United States, usually out of chagrin with the humiliating reality. Back home, others could decide to emigrate on the strength of these false reports, and only discover the sad truth upon arrival in the United States. Misguided advice it then proved, but not commercially motivated advice.

The historical evidence thus supports the narrow claim that transportation agencies then as now facilitated immigration and expanded its volume. That acknowledged, uncertainty still exists regarding whether and how widely to define the migration industry beyond the narrow confines of the transportation industry. Both Castles and Garapich include in their definition of migration industry many business interests that both Fairchild and the Dillingham Commission excluded. These are businesses that facilitate migration across borders without actually providing transportation or jobs. Castles mentions lawyers, bankers, interpreters in this category. Garapich mentions business firms that just encourage immigrant adaptation. Beauty parlors and grocery stores would fit here along with many others. True, Hernández-León limits the definition to firms that move immigrants across international borders, a position entirely compatible with that of the Dillingham Commission and of Henry Fairchild, both of whom understood labor agents and steamship companies as the exclusive source of their era's migration industry. While interested in other business interests that subserved the European migration, and deploring their work, they did not understand these businesses as part of the commercial migration industry as Castles and Garapich currently do.

\section{Bankers, prostitutes, and saloon keepers}

Three industries of the European emigration illustrate the conceptual distinction between a migration industry narrowly conceived, as nineteenth and early twentieth century authorities conceived it, and a migration industry more broadly conceived as do Garapich, Favell, and Castles. These are bankers, prostitutes, and saloon keepers. Acknowledging the woeful 
role of all of these in the European emigration, nineteenth and early twentieth century researchers did not consider them a part of the migration industry.

\subsection{Bankers}

The Dillingham Commission (US Senate 1910a: 17) counted 2,625 business firms that did a 'so-called immigrant banking business'. Of these, 116 were selected for intensive investigation. Ninety-four percent of the immigrant banks thus selected were also steamship agencies that sold international tickets. ${ }^{6}$ Immigrant customers did not have bank accounts in the immigrant banks prior to emigration from Europe. European immigrants opened these bank accounts once in the United States. The immigrants mainly employed the immigrant banks as conduits for the dispatch of remittances to the European homeland. According to Commons (1901: 4330-436), many bankers worked closely with a labor agent or padrone (Peck 2000: 2), and according to Hall (1908: 31) some bankers also were padrone, but the function of labor agent and banker are analytically separable. ${ }^{7}$ The immigrant banks were only the most visible segment of the immigrant-serving financial industry in the opinion of the Dillingham Commission (US Senate 1910a: 21). In addition, padrone, saloon keepers, grocers, and boarding house owners held deposits that had been left for safekeeping and received money for transmission abroad. ${ }^{8}$

In the opinion of public authorities, the trouble with the immigrant banking industry was its lack of regulation. Researchers never mentioned and apparently had not grasped the immigrant banks' systemic role in encouraging emigration. According to the Dillingham Commission (US Senate 1910a: 22), 'hundreds of saloon keepers and grocers act as bankers without the least fitness or equipment'. Most individuals became bankers thanks to 'the fortunate chance of their position as merchants'. Immigrant banking required very little capital investment. Opening a bank offered immigrants their only route open into the lucrative financial industry (Handlin 1979: 67). Many immigrant bankers were 'men of character' who exercised their trade in a 'thoroughly honorable way'. Unfortunately, 'ignorant, incompetent, and untrustworthy' men often swindled the immigrants out of their savings. The Dillingham Commission acknowledged that American banks 'did not solicit the patronage of the alien' for various reasons, including lack of foreign language skill among the clerks as well as 'unwillingness and inability to extend to the immigrant depositor the very necessary accommodation of patient assistance' required when dealing with poorly educated foreigners. Indeed, banking was the most visible example of 'the failure of the local institutions to meet the needs of the newly arrived immigrant' (US Senate 1910a: 22).

The Dillingham Commission understood the purposes for which immigrants entrusted their savings to co-ethnic bankers, but the Dillingham Commission was not interested in their purposes. Some remittances enabled friends and relatives still abroad to arrange their own passage to America. In this sense, the remittances of immigrants already in the United States propelled the emigration of persons still in Europe. But, as William Bailey (1912) pointed out, much of the money remitted to Europe supported friends or relatives in the homeland, paid off a mortgage there, or improved property abroad. In the former case, immigrant banks directly enabled network migration from Europe as the first arrivals sent funds back to finance the transportation of friends and relatives they left behind. But, even 
in the second case, seemingly independent of any transportation issue, the immigrant bankers enabled emigration from Europe by enabling current immigrants to accomplish their purpose in the United States. As Jenks and Lauck (1922: 23) pointed out at the time, in precocious anticipation of this line of argument, had sojourning immigrants been unable to send money home as they planned, they would not have come to the United States; without the immigrant bankers, the sending of remittances would have been much more difficult; in this sense, the immigrant bankers facilitated the emigration of sojourners as well as of settlers. Immigrant bankers facilitated and expanded immigration.

Moreover, the immigrant bankers enjoyed a virtual monopoly of banking among first generation immigrants. Lacking English skills, middle class incomes, and financial savoir faire, first generation immigrants provided the immigrant bankers, closely allied with the labor contractors, with a captive audience that was lost when an assimilated second generation reached adulthood. The immigrant bankers kept their captive banking clientele only as long as fresh immigrants continued to enter the United States (Jenks and Lauck 1922: 23). With the slowing of immigration from Europe after 1924, immigrant banks gradually disappeared by dint of the loss of their customer base, immigrants. True, a few immigrant banks made the transition to Wall Street. Thus, the Bank of Italy became the Bank of America in 1928, and left behind its earlier dependence upon an immigrant clientele. But, on the whole, the immigrant banking business collapsed when immigration ended, and the immigrant bankers knew that their business could not survive the end of immigration. The immigrant bankers had, quoting Castles, 'an interest in the continuation of migration'.

In sum, the immigrant bankers facilitated network migration from Europe, facilitated the attainment of the sojourning immigrants' financial goals, expanded immigration by dint of their services to immigrants, and consciously depended upon the continuation of emigration from Europe for their business. Therefore, following the definitions offered by Garapich and by Castles, the immigrant bankers of the late nineteenth and early twentieth century were really a second tier of the immigration industry whose first and most visible tier was the steamship companies and labor agents. If so, the immigrant banks were not just a social problem as contemporaries thought; they were a systemic part of the whole immigration process from Europe.

\subsection{Sex trafficking}

Among the European immigrants, men considerably outnumbered women (Jenks and Lauck 1922: 23). In 1910, the Census enumerated 119 foreign-born white men for every 100 foreign-born white women. An even more extreme sex ratio imbalance existed among the Chinese immigrants with comparable social consequences (Light 1974). By contrast, among the native-born whites, there were in the same decennial year 97 men for every 100 women (Light 1977: 476). The surplus of men among the immigrants strengthened demand for prostitutes. To meet this demand, the international sex traffic expanded. Organized syndicates imported women from Europe for the purpose of prostitution, and transported them to bordellos within the United States. Contemporaries called this traffic 'the white slave trade' (Zeidel 2004: 75, 116-17; Langum 1994: 15). The terminology implied that the foreign women were involuntary captives, compelled to undertake 
prostitution, and the sensational image captured the public imagination even though the Dillingham Commission's research did not substantiate it. Although native-born persons also participated in the sex industry, international traffic in prostitutes was an immigrant-dominated business in the early twentieth century (Jenks and Lauck 1922: 65; Langum 1994: 17-20). According to Henry Fairchild (1925: 334-6), 'the whole trade is fundamentally an affair of our foreign population'. The prevalence of prostitution among the foreign born was public knowledge. ${ }^{9}$ The customers of immigrant-servicing brothels represented a constituency that favored the availability of prostitution. The providers of immigrant-servicing prostitution represented a constituency that favored the continuation of immigration.

Shocked by the high incidence of prostitution among the immigrant population, many native-born Americans concluded that foreigners displayed 'a perverted sex passion' against which, some added, the Republic needed to protect itself. Prostitution was, in fact, more common in 1910 than it had been in 1810 and more common also than it would be in 2010. But, Henry Fairchild (1925: 334-6) insisted, it was profits, not passions, that animated the international sex traffic. The Dillingham Commission (US Senate 1910b: 6) similarly assigned 'to the motive of business profit' the whole 'impulse that created and upheld' the international sex traffic. 'The work is strictly foreign commerce for profit.' Jenks and Lauck similarly declared that 'the motive of business profit' underpinned this international traffic in prostitutes (1922: 66).

Many or even most European-born prostitutes had emigrated to the United States intending to pursue the oldest profession, which was already their profession in Europe. Of those who ultimately worked as prostitutes in the United States, however, at least an equal number of women entered the country expecting to meet friends or relatives, to find wage jobs, and eventually to marry (Kneeland 1911: 227-8). Naturally, many immigrant women drifted consciously into the oldest profession in response to economic incentives. However, some were tricked. Sex traffickers in Europe masqueraded as ordinary labor agents. They promised working class European women jobs as domestic servants in the United States, but, upon arrival, delivered or sold them instead to disorderly houses where they were involuntarily confined. ${ }^{10}$ Approximately a third of foreign prostitutes were illiterate, about the same level as the male immigrants. Drug addictions were common among the prostitutes. The sex traffickers who misled the European women about the bordellos that actually awaited them in the United States replicated among women the misleading propaganda that the steamship companies dished out to the emigrants in general.

The 'social evil' scandalized the American public, but the Dillingham Commission (US Senate 1910b: 24) acknowledged that American police received pay-offs from the sex traffickers in return for this industry's protection and toleration. ${ }^{11}$ The Vice Commission of Chicago (Kneeland 1911: 160) reached the same conclusion. Treating the international sex traffic as a euphemistic 'social evil', the Dillingham Commission and the contemporary journalists failed to inquire into the traffic's systemic implications for immigration. After all, the sex traffickers could pay off the American police because their international business was so profitable. Like the immigrant bankers, discussed above, prostitute-importing syndicates really belonged to a second tier of the migration industry. That is, the prostitutes were themselves immigrants, lured into the United States by labor recruiters. 
Once delivered to brothels, the foreign-born prostitutes serviced vast numbers of lonely men whose integration into family life had been disrupted by immigration. The immigrant men who dug the tunnels, mined the coal, and built the railroads were not monastics. They sought commercial sexual outlets in order to improve their perceived quality of life in a foreign country where they worked long hours in hazardous industries at low pay. Just as the 'hookers' who followed the union armies during the Civil War were part of Abraham Lincoln's war effort, so immigrant prostitutes were part of American industrialization in the late nineteenth and early twentieth centuries. It is even true, as events showed, that when the cessation of immigration brought a normalization of the sex ratio among the American population, demand for foreign prostitutes subsided, and the international sex traffic withered away. In this sense, the international sex traffic depended upon the continuation of migration fully as much as did the steamship companies and labor agents (Light 1977).

\subsection{Saloon keepers}

Alcohol abuse was the anti-drug crusade of the late nineteenth and early twentieth centuries. Unlike the native-born evangelical Protestants, who embraced temperance, immigrants drank wine, schnapps, and beer with the blessing of their churches (Langum 1994: 16). The divergent immigrant and native attitudes toward alcohol amounted to a cultural conflict. For this reason, Methodist and Baptist crusades against saloons were implicitly anti-immigrant in character even when they were not openly so, which they often were. Moreover, the nascent women's movement embraced temperance in the avowed hope of compelling wayward husbands to bring their whole paycheck home. Temperance was about paychecks, not just sobriety, and thus about a woman's and her children's right to share her husband's income. Like the rest of the American public, temperance reformers believed sensational reports of drunkenness that exaggerated the insobriety that went on in the saloons that immigrant men patronized. With the exception of Carrie Nation, the axwielding enforcer of the temperance movement, respectable women did not enter saloons so first-hand knowledge of what transpired in them was unavailable to the temperance crusaders, who ultimately brought about the Prohibition era (1920-1933).

The popular media depicted immigrant saloon keepers as depraved and immoral individuals who led working men into alcoholism, spousal abuse, and child neglect. ${ }^{12}$ of course, heavy drinking was as insalubrious then as it is today. But popular media exaggerated the extent of insobriety in saloons. Early social research studies yielded a more balanced and friendlier picture of what service immigrant saloon keepers actually delivered. An early sociologist, John Koren (1899) undertook an exemplary ethnographic study of saloons in Chicago's ninth ward, a heavily immigrant and working-class area. He visited 200 saloons that serviced a population of 48,000 persons, approximately one saloon for every 240 residents. Koren described the saloons as a community 'loafing place, news centre, place for discussion, and common meeting ground' whose 'free lunch counter' propped up the men's diet. Saloons of the ninth ward did not 'stand for intemperance' among the clientele. Only three drunks were found in the 200 saloons. Of the 200 saloons, the police had identified two as servicing thieves and one as 'an assignation house.' Although he observed some ethnic differences in drinking patterns (Table 1), Koren 
Table 1. John Koren on ethnic saloons

\section{Italian Saloons}

'Drinking to the point of intoxication is the exception in these saloons, for the Italians are a temperate people.'

\section{German Saloons}

'One observes in them a large consumption of beer and various foods, little visible intoxication, and an air of heartiness (Gemütlichkeit) all the German's own. It is expected that the patron will take his ease here, every convenience being afforded for that purpose; and other means than drinking are at hand to pass the idle hour.'

\section{Irish Saloons}

'...the most representative Irish saloons stand for immoderate drinking and drunkenness in greater measure than any others. Nevertheless, [even] where the hardest drinking prevails, for instance in the saloons frequented by sailors and longshoremen... it is undeniable that the desire for sociality is one of the chief attractions.'

Source: Koren (1899: 223-9)

stressed the sociality saloons everywhere provided the patrons. Koren everywhere saw many working-class men playing cards, reading newspapers, and spending an entire evening over one glass of beer.

Koren declared the saloon a workingman's club where the men passed the time in sociability with their fellows. Saloon habitués were disproportionately bachelors appreciably older than the average age of marriage for American men. For these bachelors, family did not provide any haven from a heartless world. Saloons were the immigrant men's extended family, university, debating society, and club house. Saloon keepers themselves were often successful ex-workingmen (Fairchild 1925: 158-9) connected to the political machine's power system, and enabled through it to hand out occasional jobs and favors from City Hall. Saloons even had flushing toilets when most residences did not. Some saloon keepers doubled as immigrant bankers. ${ }^{13}$ If a workingman fell into need, the saloon keeper, a man with 'a warm heart and a glad hand', might provide some philanthropic relief. In an era before television sets and welfare departments, the saloons combined some elements of both (Koren 1899: 210-20).

Saloons attracted the patronage of men from the same village or region in Europe, who knew each other well from the homeland, and who supported one another socially and economically in the United States (Rothbart 1993: 341-2). When the immigrants' second generation emerged, and ties to village and region waned, saloon keepers lost this spontaneous clientele, and had to merge into the general ethnic group in order to survive economically. Some saloon keepers took their ethnic saloon into the mainstream, inviting non-coethnics to sample a previously Irish, Italian, Slovak or German saloon. McSorley's Old Ale House in Lower Manhattan is a celebrated survivor of this transition. ${ }^{14}$ For the most part, however, the ethnic saloons did not survive the end of the European immigration to which they were economically tied. The Prohibition era (1920-1933) was one 
obvious reason. Saloon keeping became illegal in this period. But more important in the long run was the assimilation of the immigrants, the rise of other forms of commercial recreation, abundantly charted by the Chicago School sociologists, the collapse of political machines, and the emergence of the welfare state. All of these developments undermined the cozy, ethnic saloon as a social center.

Were saloons part of the migration industry? They did not sell steamship tickets; so, if selling tickets be the sole defining criterion, the answer must be no. On the other hand, the saloons were social service providers in the immigrant communities. Immigrant men needed opportunities for sociability, employment agencies, welfare support, recreation, political connections, and alcohol-assisted relaxation. Saloons provided all of these on a commercial, for-profit basis. Without the saloons, the life quality of the immigrants would have been drearier than it actually was, the quality of immigrant men's life would have declined, reducing their immigration to the United States, and possibly slowing the pace of industrialization. For their part, the saloons depended on the continuous immigration to provide their bachelor clientele. Depending on immigrants for one's commercial clientele is a badge of membership in a migration industry. If we acknowledge that the ethnic saloons supported the immigrants already here with critical services, contributed to the attractiveness of the United States as a destination for immigrants, and consciously depended for their clientele upon continued immigration, then we have defined the saloons as a second tier of the migration industry.

\section{Conclusion}

Late nineteenth and early twentieth century researchers were aware of the role of labor agents and steamship companies in stimulating and encouraging immigration from Europe. Although they did not use the term 'migration industry' they might well have done so, for the concept is implicit in their discourse. Additionally, immigration authorities attempted to discourage and frustrate the operation of the migration industry out of the belief that the migration industry peddled rosier images of what the United States offered immigrants than what the sober truth would have allowed. As a result, they thought, the migration industry induced more working-class Europeans to emigrate than would otherwise have done so, causing social problems among the supernumerary immigrants. However, legal measures to frustrate the migration industry failed, and migration from Europe continued to exceed what reformers and researchers regarded as an optimal level. As a result, the actual immigration levels were higher than they otherwise would have been.

Addressing immigrant banks, prostitute-importing syndicates, and immigrant saloons, except for Jenks and Lauck, who mentioned and partially theorized them, late nineteenth and early twentieth century researchers ignored the manner in which each of these migration industries contributed to the appeal of the United States as a destination for European workers. That is, the researchers failed to pursue a systemic understanding of how immigrant banks, immigrant prostitutes, and immigrant saloons supported continuing immigration from Europe, improved the life quality of immigrants in the United States, and depended for their clientele upon continued immigration. Had they done so, they would have found that immigrant banks, immigrant prostitutes, and immigrant saloons 
represented a second tier of the migration industry that supported the first tier of steamship companies and labor agents.

Generally speaking, the current concept of migration industry continues to grapple with exactly this issue. How broadly shall we draw the boundaries of the migration industry? Should the migration industry be limited to transportation-related business firms or should it even include the entire ethnic enclave economy? Why not add co-ethnic barber shops, grocery stores, health care professionals, and so forth to the second-tier migration industry? This article has argued that defining the migration industry as transportation agencies is overly narrow today as it was a century ago. A narrow focus on transportation ignores the systemic support that many other commercial agencies provided and provide to immigrants even when they do not directly concern themselves with transport or promises of employment. The conceptual issue is basically whether, in the absence of this or that industry's systemic support of immigrants' quality of life abroad, immigration would diminish in volume; and, second, whether immigration-dependent business owners understand their dependency upon immigrant customers. If the answer is yes to both, then all immigrant-oriented commercial business should be regarded as a second-tier contributor to the migration industry, and a facilitator of immigration.

Conflict of interest statement. None declared.

\section{Notes}

1. van Liempt and Doomernik (2006) basically follow Salt and Stein, but attempt to introduce some agency for smuggled migrants, who are not mere pawns in someone else's game.

2. The Immigration Act of 1924 limited the annual number of immigrants who could be admitted from any country to 2 percent of the number of people from that country who were already living in the United States in 1890 . Subsequently amended, the law's intent was always to restrict southern and eastern European immigration as well as to prohibit the immigration of Middle Easterners, East Asians, and Asian Indians.

3. The Page Act of 1875 restricted the access of designated 'undesirables', among whom were specifically enumerated Asian prostitutes and Chinese coolies. The Page Act did not prohibit the entry of Chinese as such. The Chinese Exclusion Act of 1882 required the United States to suspend Chinese immigration, merchants excepted.

4. 'This legislation marked the real beginning of the systematic examination of immigrants at United States ports, and the number of rejections which resulted soon compelled steamship companies to exercise some degree of care in the selection of steerage passengers at foreign ports.' Dillingham Commission (US Senate 1911: 70)

5. German officials wanted to prevent the settlement of Polish immigrants within the eastern provinces of Germany so this border control was in Germany's interest too. (Castles 2007: 33; also, Zolberg 2006: 206)

6. 'It is not meant to say that only steamship agents become bankers, nor that all immigrants who are doing a banking business are actively engaged in the selling of steamship 
tickets, but only to point out that the steamship agency is the most general antecedent of the immigrant bank.' (US Senate 1910a: 21)

7. 'But the padrone... works together with the Italian banker, who is a somewhat more responsible party than the padrone... because it is through him that they send money back to Italy, and with whom they keep their small savings. It is through the banker that the call is made for the number of men who are wanted, and it is in his office where the arrangements with the men are made. He may advance the money for transportation and even the commission if the men do not have the money. The padrone takes charge of the men in the capacity of a boss, takes them to the place of work, runs the boarding house or shanty store at the place of work, and acts as interpreter for the contractor...' (Commons 1901: 432). For an extended treatment of the padrone, see also Nelli (1970: 55-87).

8. Immigrant groups in the United States continue to found banks for much the same reasons as in the past. See Shanmuganthaan, Stone and Foss (2004).

9. 'The white slave traffic aroused tremendous public interest early in this century, and was thoroughly exploited in the daily and periodical press.' (Fairchild 1925: 334)

10. '.. . testimony shows that when an importer sells a girl to a disorderly house keeper or to a pimp, and frequently into what is practically slavery, he often receives $\$ 500$ or more, in certain cases twice or three times that sum; an amount sufficient to cover the expense to which he has been put in securing the girl, his own expenses, and a substantial profit.' (US Senate 1910b: 30)

11. 'Most of the girls questioned by the commission's agents ... said that payments were made to the police to insure their protection from too frequent arrests. It is, of course, a violation of the law for the police to demand or receive such money; but the woman who did not pay for protection was frequently arrested.' (US Senate 1910b: 27)

12. 'With superabundant evidence of the manifold ills flowing from intemperance, it is natural that the saloon, as the fountain-head and distributing centre of intoxicating drink, should have come to be regarded as typifying the vast evils resulting from the liquor habit, and nothing more.' (Koren 1899: 210)

13. 'As a rule, the depositors in these banks are immigrant laborers ... The grocer or saloon keeper who operates a bank derives his patronage from his customers; boarding bosses depend upon their boarders. In the case of all, a large amount of money comes in by mail from laborers who have been sent out to work through the efforts of the proprietor. There is a distinct tendency on the part of immigrant laborers to continue, regardless of a change of residence, to send remittances home through the banks to which they have become accustomed.' (US Senate 1910a: 47)

14. 'Established in 1854, McSorley's can boast of being New York City's oldest continuously operated saloon. Women were finally allowed access ... in 1970.'

\section{References}

Bailey, W. B. (1912) 'The Bird of Passage', American Journal of Sociology, 18: 391-7.

Bodnar, J. (1985) The Transplanted: A History of Immigrants in Urban America. Bloomington: Indiana University Press. 
Castles, S. (2007) 'The Factors That Make and Unmake Migration Policies', in Portes, A. and DeWind, J. (eds), Rethinking Migration: New Theoretical and Empirical Perspectives, pp. 29-61. New York: Berghahn.

Commons, J. (1901) 'The Padrone System and Common Labor', in Reports of the United States Industrial Commission, Vol. 15, pp. 430-6. Washington, DC: Government Printing Office.

De Haas, H. (2010) 'The Internal Dynamics of Migration Processes: A Theoretical Inquiry', Journal of Ethnic and Migration Studies, 36/10: 1587-617.

Fairchild, H. P. (1925) Immigration: A World Movement and its American Significance. New York: Macmillan.

Favell, A. (2008) 'The New Face of East-West Migration in Europe', Journal of Ethnic and Migration Studies, 34/5: 701-6.

Garapich, M. P. (2008) 'The Migration Industry and Civil Society: Polish Immigrants in the United Kingdom Before and After EU Enlargement', Journal of Ethnic and Migration Studies, 34/5: 735-52.

Hall, P. F. (1908) Immigration and Its Effects upon the United States. New York: Henry Holt.

Handlin, O. (1979) Boston's Immigrants. Cambridge, MA: Harvard University Press.

Herman, E. (2006) 'Migration as a Family Business: The Role of Personal Networks in the Mobility Phase of Migration', International Migration, 44/4: 191-230.

Hernández-León, R. (2008) Metropolitan Migrants: The Migration of Urban Mexicans to the United States. New York: Russell Sage.

Hourwich, I. A. (1912) Immigration and Labor. New York: G. P. Putnam's Sons.

Jenks, J. W. and Lauck, W. J. (1922) The Immigration Problem. 6th edn. New York: Funk and Wagnalls.

Johnston, M. F., Karageorgis, S. N. and Light, I. (2013) 'US Ethnic Economic Conditions Affect Mexican Population Growth in New Destinations: Using Census Data to Engage the Social Capital Theory of Migration', Journal of Ethnic and Migration Studies, in press.

Kamphoefner, W. D. (2009) 'Immigrant Epistolary and Epistemology: On the Motivators and Mentality of Nineteenth-Century German Immigrants', Journal of American Ethnic History, 28/3: 34-54.

Kneeland, G. J. (1911) The Social Evil in Chicago. Chicago, IL: Vice Commission of the City of Chicago.

Koren, J. (1899) Economic Aspects of the Liquor Problem. Boston, MA: Houghton, Mifflin.

Langum, D. J. (1994) Crossing the Line: Legislating Morality and the Mann Act. Chicago, IL: University of Chicago Press.

Light, I. (1974) 'From Vice District to Tourist Attraction: The Moral Career of American Chinatowns, 1880-1940', Pacific Historical Review, 43: 367-94.

_ (1977) 'The Ethnic Vice Industry, 1880-1944', American Sociological Review, 42/3: 464-79.

(2006) Deflecting Immigration. New York: Russell Sage.

_ \& Sabagh, G., Bozorgmehr, M. and Der-Martirosian, C. (1994) 'Beyond the Ethnic Enclave Economy', Social Problems, 41: 601-16.

Lindquist, J. (2010) 'Labour Recruitment, Circuits of Capital and Gendered Mobility: Reconceptualizing the Indonesian Migration Industry', Pacific Affairs, 83/1: 115-32. 
Massey, D. (1999) 'Why Does Immigration Occur?', in Hirschman, C., Kasinitz, P. and DeWind, J. (eds), The Handbook of International Migration, pp. 34-52. New York: Russell Sage Foundation.

— \& Alarcon, R., Durand, J. and Gonzalez, H. (1987) Return to Aztlan. Los Angeles, CA: University of California Press.

Nelli, H. S. (1970) The Italians in Chicago, 1880-1930. New York: Oxford University Press. Park, R. (1922) The Immigrant Press and its Control. New York: Harper and Brothers.

Peck, G. (2000) Reinventing Free Labor. Cambridge: Cambridge University Press.

Rath, J. and Swagerman, A. (2011) Promoting Ethnic Entrepreneurship in European Cities. Luxembourg: Publications Office of the European Union.

Rothbart, R. (1993) 'The Ethnic Saloon as a Form of Immigrant Enterprise', International Migration Review, 27: 332-58.

Salt, J. and Stein, J. (2002) 'Migration as a Business: The Case of Trafficking', International Migration, 35/4: 467-94.

Shanmuganthaan, P., Stone, M. and Foss, B. (2004) 'Ethnic Banking in the USA', Journal of Financial Services Marketing, 8: 388-400.

United States Senate (1910a) 'Origin and Character of Immigrant Banks', Reports of the Immigration Commission, Vol. 37. Washington, DC: Government Printing Office.

- (1910b) 'Importing Women for Immoral Purposes', Reports of the Immigration Commission, Vol. 37. Washington, DC: Government Printing Office.

- (1911) 'Emigration Conditions in Europe', Reports of the Immigration Commission, Vol. 4. Washington, DC: Government Printing Office.

van Liempt, I. and Doomernik, J. (2006) 'Migrant's Agency in the Smuggling Process: The Perspectives of Smuggled Migrants in the Netherlands', International Migration, 44/4: 165-90.

Zeidel, R. F. (2004) Immigrants, Progressives, and Exclusion Policies. DeKalb, IL: Northern Illinois University Press.

Zolberg, Aristide R. (2006) A Nation by Design. Cambridge: Harvard University. 